\title{
A CASE OF ADHESIVE SMALL BOWEL OBSTRUCTION WITH PELVIC INFLAMMATORY DISEASE DUE TO CHLAMYDIA TRACHOMATIS
}

\author{
Ji-Eun Lee, MD¹, Myounghwan Kim, MD¹, Hoon Choi, MD1', Ji-Kyung Ko, MD¹, Chulmin Lee, MD', \\ Yongkyoon Cho, MD'1, Bokrin Kim, MD'1, Keunho Yang, MD², Ji-Eun Kwon, MD³ \\ Departments of ${ }^{1}$ Obstetrics and Gynecology, ${ }^{2}$ Surgery, ${ }^{3}$ Pathology, Sanggye Paik Hospital, Inje University College of Medicine, Seoul , Korea
}

\begin{abstract}
A 17-year-old woman, who was hospitalized because of pelvic inflammatory disease due to Chlamydia trachomatis, developed emesis on 5th hospital day. On 7th day, vomiting and abdominal pain was aggravated. Plain radiography and contrast enhanced abdominopelvic computed tomography (CT) scan revealed small bowel obstruction with possible ischemic change at the level of the mid to distal ileum. Emergent exploratory laparotomy wad done and revealed adhesive band between small bowel mesentery and omentum, which resulted in closed loop and small bowel obstruction. Partial omentectomy, adhesive band adhesiolysis and incidental appendectomy was done. After surgery, the symptom was completely resolved with no further recurrence after outpatient department follow-up for 11 months. The present case calls for inclusion of abdominopelvic CT scan as well as plain radiography of the abdomen in the evaluation of pelvic inflammatory disease (PID) associated with emesis to detect bowel obstruction, rare sequlela of PID.
\end{abstract}

Keywords: Small bowel obstruction; Pelvic inflammatory disease; Chlamydia trachomatis

Chlamydia trachomatis (C. trachomatis)는 세포내에서만 살 수 있는 그람 음성균으로서, 주로 비뇨기 생식기와 눈에 감염을 일으키며 현재 성매개병의 가장 흔한 원인균으로 알려져 있다. 또한 감염 환자의 약 20\%-30\%에서는 증상이 없거나 병의 진행이 비특이적이어서 정확한 진단을 하지 못하는 경우가 있고, 임신여성의 $4 \%-20 \%$ 에서 배양될 정 도로 높은 빈도를 나타내고 있어 이것이 C. trachomatis 감염의 급격한 증가 요인이 되고 있다[1].

골반염증질환은 성적 활동이 활발한 여성에게서 일어나는 심각한 상행성 여성생식기 감염이다. 원인균으로 Neisseria gonorrhea ( $N$. gonorrhea) C. trachomatis 그 밖의 다양한 혐기성 및 호기성 균주들 이 있다. 골반염증질환을 가진 여성의 $25 \%$ 에서는 난관난소농양, 불임 증, 만성골반통, 또는 자궁외임신을 포함하여 합병증으로 고통을 받게 된다. 골반내 감염이 복막 또는 림프선 및 혈행성 확산에 의해 생식기 로부터 복강내로 확산되어 복막염(generalized peritonitis)을 일으킬 수 있다. 간 주위와 간 피막으로 전파되는 경우를 간주위염(Fitz-HughCurtis syndrome)이라고 하고 골반염증질환 환자의 $5 \%-27 \%$ 에서 발 생한다[2].

간주위염 환자의 3분의 2에서 오른위사분역(right upper quadrant) 통증이나 흉막성 통증을 호소한다. 과거에 N. gonorrhea가 가장 흔한 원인균으로 생각되었으나 C. trachomatis가 더 흔한 원인균으로 여겨지
고 있다[3].

C. trachomatis 감염은 N. gonorrhea이나 다른 균들보다 전반적인 복막 증상이 적고 무증상인 경우도 있다. 하지만 소수의 경우에서 $C$. trachomatis 감염이 전신적 또는 국소적 복막염을 일으켜 위장관 폐쇄 를 일으키고 진단과 치료를 위해 복강경 또는 개복술이 필요할 수도 있다[4].

C. trachomatis 감염에 의한 골반염증질환과 동반된 유착성 소장폐쇄

Received: 2011.11.23. Accepted: 2012.1.14.

Corresponding author: Myounghwan Kim, MD

Departments of Obstetrics and Gynecology, Inje University Sanggye Paik Hospital, Inje University College of Medicine,

Sanggye 7-dong, Nowon-gu, Seoul 139-707, Korea

Tel: +82-2-950-1621 Fax: +82-2-938-4108

E-mail: myankim@paik.ac.kr

This is an Open Access article distributed under the terms of the Creative Commons Attribution Non-Commercial License (http://creativecommons.org/licenses/ by-nc/3.0/) which permits unrestricted non-commercial use, distribution, and reproduction in any medium, provided the original work is properly cited.

Copyright $\odot$ 2012. Korean Society of Obstetrics and Gynecology 


\section{KOREAN JOURNAL OF OBSTETRICS \& GYNECOLOGY}

Ji-Eun Lee, et al. Small bowel obstruction secondary to PID

에 대해 세계적으로 보고된 예는 보존적 치료를 시행한 경우 1예, 복강 경 수술로 치료한 경우 2예, 개복술로 치료한 경우 3예로 극소수였다 [4-10]. 국내에서는 소장 폐쇄가 동반된 chilaiditi syndrome으로 진단 된 환자를 소장절제술로 치료한 경우가 있었고 수술 소견으로 소장폐 쇄의 원인이 과거에 않고 지나간 간주위염 때문이었다고 판단할 수 있 었다[11].

저자들은 C. trachomatis 감염에 의한 골반염증질환 환자를 치료하던 중 오심과 구토가 발생하여 시행한 복부골반 컴퓨터단층촬영에서 허혈 성 소장폐쇄가 의심되어 개복술을 시행한 환자에게서 골반염증질환에 의한 이차적인 유착성 소장폐쇄로 판명된 증례를 문헌 고찰과 함께 보 고하는 바이다.

\section{증 례}

환 자: 박 $O$ 현, 17 세, 미혼 산과력: 0-0-0-0

월경력: 12 세에 초경을 시작하여, 월경주기는 30 일로 규칙적이었고 기간은 4일이었으며 양은 보통이었다.

과거력: 특이사항 없었다.

가족력: 특이사항 없었다.

현병력: 병원 방문 11일 전부터 간헐적으로 오른아래사분역(right lower quadrant) 통증이 있어서 방문 3일 전부터 개인의원에서 치 료받던 중 통증이 심해지고 찌르는 듯한 오른위사분역(right upper
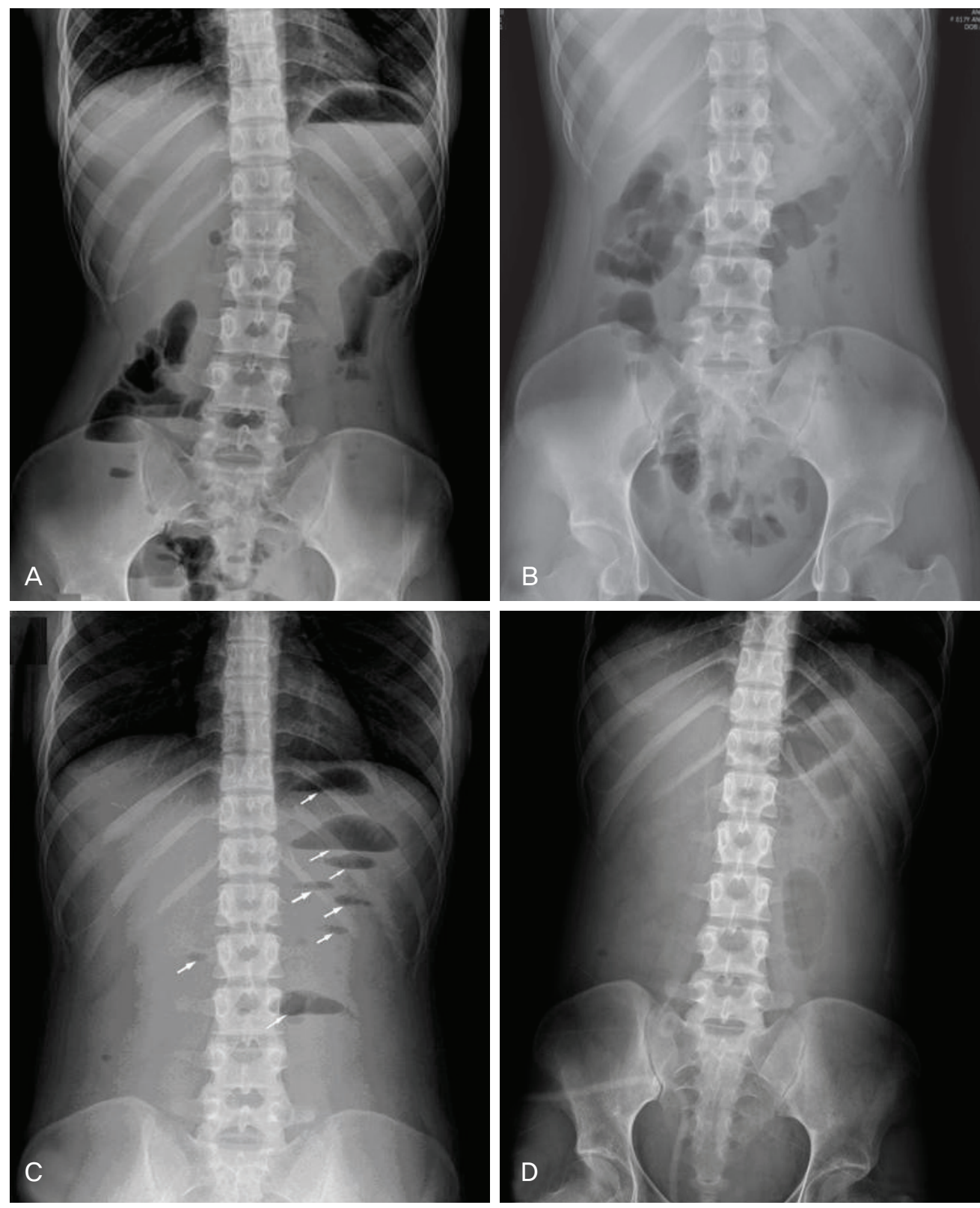

Fig. 1. Plain abdominal radiography. Upright $(A)$ and supine $(B)$ abdominal radiographs showed focal ileus in right upper quadrant and pelvic cavity and there is no small bowel dilatation and normal transverse colon gas shadow is seen on day 1 of hospitalization, whereas on day 7 upright (C) abdominal radiograph shows multiple air-fluid level (arrows) in small bowel and supine (D) abdominal radiograph showed dilated small bowel with no gas seen in colon that it meaned developing small bowel obstruction. 
quadrant) 통증이 동반되어 응급실에 왔다. 통증의 양상은 지속적이고 쑤시는 듯 하였으며 오심이나 구토, 변비, 설사 등의 위장관 증상은 없 었다. 환자는 16 세부터 성적 활동이 활발하였으며 간헐적으로 콘돔을 사용하였다.

이학적 소견: 환자의 키는 $154 \mathrm{~cm}$, 체중은 $46 \mathrm{~kg}$ 이었으며, 활력 징후 는 혈압은 $119 / 80 \mathrm{~mm} \mathrm{Hg}$, 맥박은 84 회/분, 체온은 $37.9^{\circ} \mathrm{C}$, 호흡수는 18 회/분이었다. 복부진찰에서 오른아래사분역과 오른위사분역에 압통 은 있으나 반동압통은 없었으며 머피 징후(Murphy’s sign)는 양성이었 다. 골반진찰에서 자궁경부움직임압통과 우측자궁 부속기 압통이 있 었으며, 자궁경부와 질에 중등도의 백색 점액 분비물이 있었다. 장음은 정상이었고 그 밖의 신체 진찰에서 특이 소견은 없었다.

검사 소견: 소변임신반응은 음성이었다. 헤모글로빈 $13.4 \mathrm{~g} / \mathrm{dL}$, 적혈 구용적률 $39.8 \%$, 백혈구 $10,940 / \mathrm{mm}^{3}$ (중성구 분율 $72.4 \%$ ), 혈소판 $340,000 / \mathrm{mm}^{3}$ 이었고, 혈당, 전해질, 간기능검사, 빌리루빈 수치, 신기 능검사, 전해질검사, 요검사에서 정상 소견을 보였고 사람면역결핍바 이러스검사, 매독검사, $\mathrm{B}$ 형 간염항원검사는 음성이었다. 적혈구침강속 도는 $77 \mathrm{~mm} / \mathrm{hr}$ 로 증가되어 있었고 C-반응단백질도 $2.3 \mathrm{mg} / \mathrm{dL}$ 로 증
가되어 있었다.

자궁경부 분비물을 채취하여 다중 중합효소연쇄반응 검사인 sexually transmitted disease polymerase chain reaction 6종 검사(Seegene, Seoul, Korea)를 시행하였으며 C. trachomatis가 검출되었다.

단순복부촬영에서 특이 소견이 없었고(Fig. 1A, 1B) 경질 초음파검사 에서도 부속기 종양이나 농양은 보이지 않았다. 복부골반 컴퓨터단층 촬영에서 복강과 간주위 조직에 염증성 변화와 소량의 복수가 관찰되 는 것 외에 특이 소견은 없었다(Fig. 2).

입원 후 경과: 골반염과 그에 따른 간주위염으로 진단하고 3세대 세팔 로스포린 항생제(ceftriaxone)와 메트로니다졸(metronidazole)을 정맥 투여하였으며 독시사이클린(doxycyline)을 경구 투여하였다. 환자의 복 통은 호전되고 있었다. 입원 5일째부터 갑자기 심와부(epigastrium) 통 증과 오심, 구토 증상을 호소하였다. 장음은 정상이었고 복부는 부드 럽게 촉지되었으며 단순복부촬영결과에서 특이 소견은 보이지 않았 다. 골반염에 동반된 장관염이 의심되어 환자를 금식시키고 항구토제 (metoclopramide)와 비스테로이드성 진통제(ketorolac)를 투여하였다. 증상이 일시적으로 경감되었으나 호전되지는 않았다. 입원 6일째에도
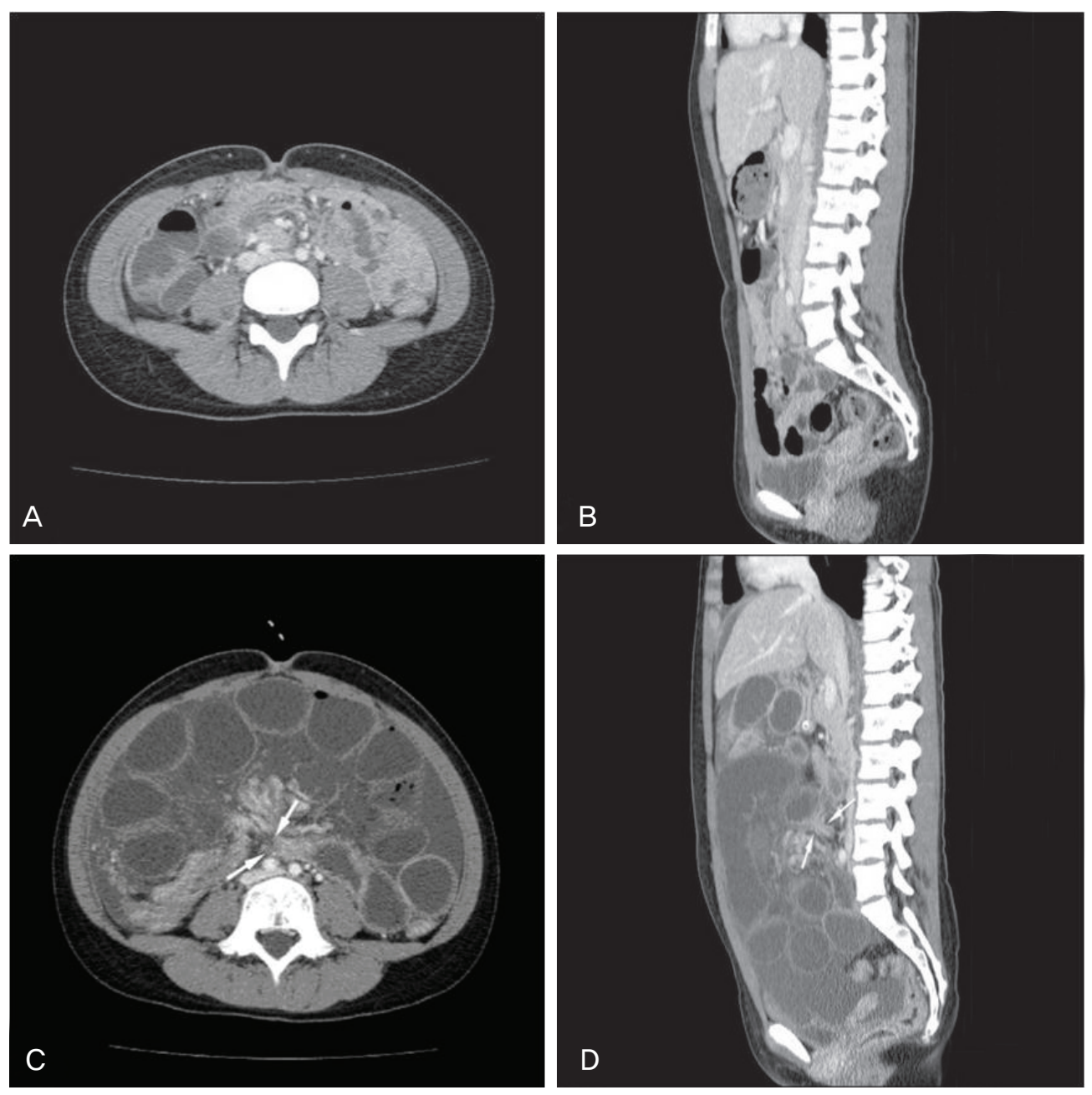

Fig. 2. Contrast-enhanced computed tomography (CT) scan. Axial (A) and sagittal (B) CT scan show no evidence of dilated small bowel on day 1 of hospitalization, whereas on day 7 axial (C) and sagittal (D) CT scan show dilated, fluid-filled small bowel to the level of an adhesion in the ileum and note the collapsed segment of bowel (arrows) that it meaned transition zone. 


\section{KOREAN JOURNAL OF OBSTETRICS \& GYNECOLOGY}

Ji-Eun Lee, et al. Small bowel obstruction secondary to PID
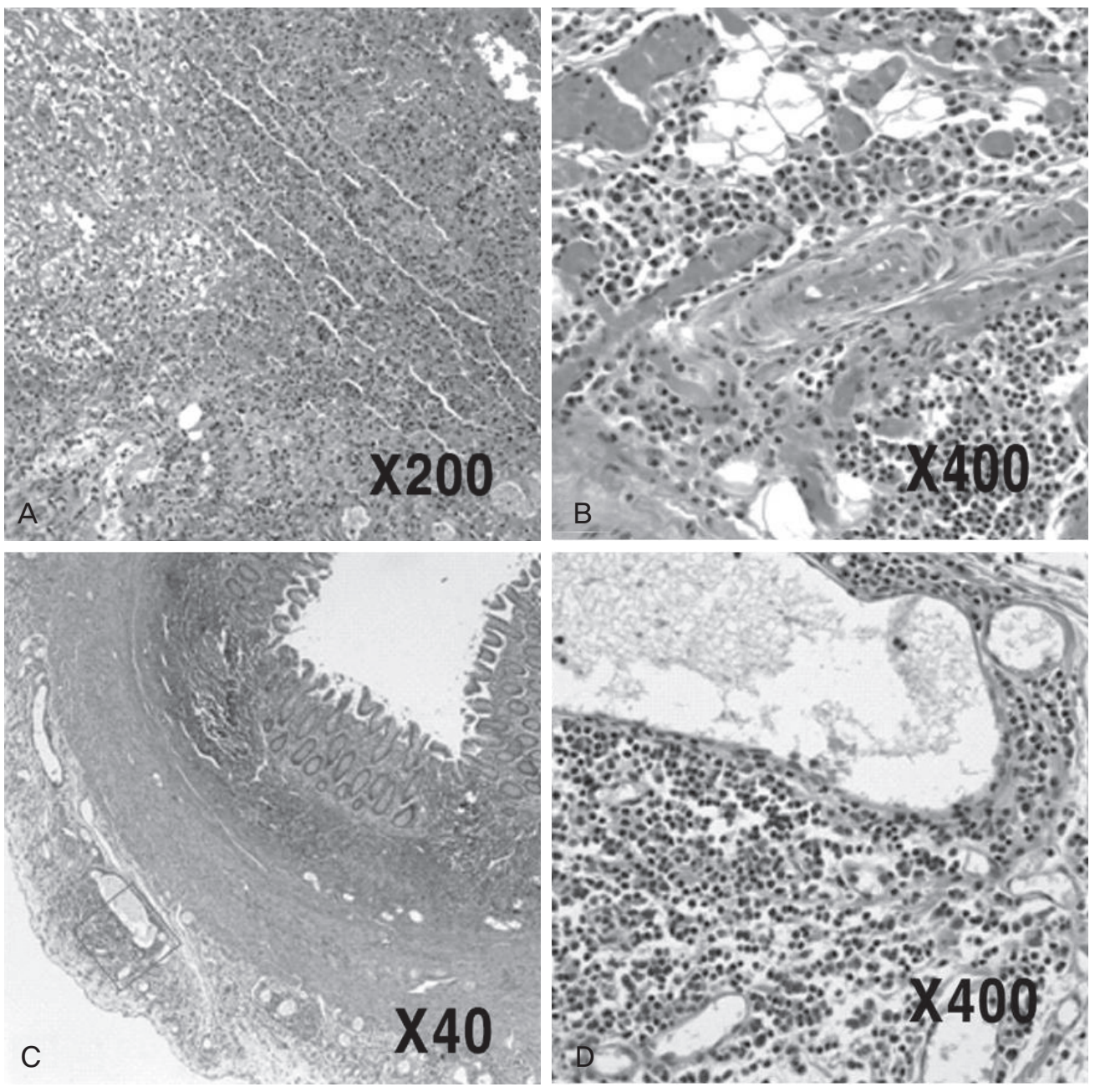

Fig. 3. The omentum shows multifocal abscess formation mixed with blood, fibrinous exudates ( $H \& E$, $\times 200)(A)$, areas of lymphoplasmacytic infiltration $(H \& E, \times 400)(B)$, and the appendix shows lymphoplasmacytic infiltration predominantly along the subserosal layer $(H \& E, \times 40)(C) H \& E, \times 400$ (D).

복부 진찰 및 단순복부촬영에도 특이 소견이 없었고 외과 협진에서 현 재대로 보존적 치료를 지속하며 경과관찰하자고 하였다. 입원 7일째 장음이 감소하고 복부가 팽만되었으며 단순복부촬영에서 장폐쇄 소견 과 복수가 관찰되었다(Fig. 1C, 1D). 코위관 삽입 후 외과 재협진 후 복 부골반전산화단층촬영을 다시 시행하였다. 입원 시 시행한 복부골반 전산화단층촬영과 비교해, 유착띠로 인해 중간부에서 원위부 소장이 끼어있는 폐쇄고리(closed loop)를 형성하고 있었다. 허혈성 변화도 있 는 소장폐쇄(Fig. 2C, 2D) 소견을 보였다. 복강과 골반강내 다량의 복수 도 관찰되었다. 외과에서 응급 시험적 개복술을 시행하였다.

수술 소견: 배꼽 아래 수직 정중 복부절개를 하였고, 복강내 $1,500 \mathrm{~mL}$ 의 복수가 관찰되었다. 허혈 변화가 있을 수 있는 소장을 찾기 위해 소 장 위에 덮혀져 있는 그물막을 걷어내었다. 그물막은 얇게 형성되어 그 물막 주변으로 염증이 형성되어 있었고 소장간막과 유착되어 있었다. 그물막과 장간막 사이에 약 $3 \mathrm{~cm}$ 정도 되는 타원형 공간인 유착띠가 형성되어 그 공간으로 약 $20 \mathrm{~cm}$ 정도 근위부회장이 끼어 폐쇄고리를 형성하고 있었다. 충수돌기 주변과 양쪽 자궁부속기 주변에도 염증 소 견이 있었다. 소장간막과 그물막 사이 유착으로 형성된 유착띠를 박리
하고 확장된 근위부회장을 유착띠가 형성된 공간에서 끄집어내어 근위 부회장의 색깔과 연동운동을 확인하였으며 괴사소견은 보이지 않았다. 염증으로 유착된 그물막 부위를 부분그물막절제술을 시행하였고 부수 적으로 충수돌기절제술을 시행하였다.

병리검사결과: 절제된 그물막은 $15 \times 6 \mathrm{~cm}$ 정도였고 림프구와 형질세 포의 미만 침윤이 관찰되는 급성과 만성 비특이적 염증 소견이 보였다 (Fig. 3A, 3B). 절제된 충수돌기는 직경 $0.5 \mathrm{~cm}$, 길이 $4 \mathrm{~cm}$ 였고 장막은 황색 염증 삼출액으로 덮여 있었으며 관경(lumen)은 혼탁한 갈색 분비 물로 차 있었다. 림프구와 형질세포의 침윤이 장막하층을 따라 관찰되 는 장막하 만성염증소견이 보였다(Fig. 3C, 3D).

수술 후 경과: 증상이 호전되어 특별한 합병증 없이 퇴원하였고, 이후 11 개월간의 외래 추적 기간 동안 특이 소견은 보이지 않았다.

\section{고 찰}

미생물이 자궁경관 점막에 군집화된 후 자궁내막과 나팔관을 따라 
서 상부생식기에 감염 및 염증을 일으키는 것을 골반염증질환이라 한 다. 급성기에는 골반 동통과 자궁경부움직임 압통 등의 국소적 및 전신 적 여러 증상을 보이고 주요 원인균은 N. gonorrhea와 C. trachomatis 이다. 과거에는 N. gonorrhea가 가장 많은 빈도를 보였으나, 현재는 $C$. trachomatis의 비율이 점차 증가되어 이제는 골반염증질환의 가장 흔 한 원인으로 인식되고 있다[3]. 국내 보고에서 C. trachomatis의 이환율 은 골반염증질환이 있는 환자들에게서 $20.6 \%$, 증상이 없는 경우에서 $8.6 \%$ 가 검출되었고 호발 연령은 20 대 후반이었으며 유산의 기왕력이 있는 경우가 없는 경우보다 더 많았다[11].

C. trachomatis의 주요 합병증에는 골반염과 난관성 불임, 자궁외 임신이 있는데 골반염의 경우 잠복성(silent)이라 불릴 만큼 증상이 경 미하고 서서히 진행되어 진단이 매우 어렵고 발견되지 않고 지나가 는 경우도 있다. 성적으로 활동적인 여성에게서 원인불명의 복막염이 있을 경우 C. trachomatis 감염을 의심해야 한다는 보고도 있다[8,9]. C. trachomatis 골반염증질환의 $25 \%$ 에서 장기적인 만성적 하복부 통 증, 불임 등의 심각한 합병증을 동반하게 된다[12]. 난관불임의 3 분 의 2, 자궁외임신의 3 분의 1 에서 C. trachomatis가 원인이기 때문에 C. trachomatis 선별검사를 자궁경부암 검진과 같이 일상적으로 시행 하자고 주장하는 학자들도 있다[7]. 미국의 질병관리본부(Center for
Disease Control)에서는 사회경제적으로 낮은 계층의 젊은 여성, 다수 의 성교상대를 가진 여성, 성병에 대한 기왕력이 있는 여성, 20세 이하 의 임신부와 같은 고위험군에 대해서 감염유무에 대한 검사 및 치료를 권장하고 있으며, 또한 성적 접촉 상대자에 대해서도 추적검사와 치료 를 권장하고 있다[13]. 또한 $C$. trachomatis 감염은 사람면역결핍바이 러스 감염의 성적 전파를 촉진시키는 중요한 위험인자로도 제시되고 있다.

C. trachomatis 감염의 진단은 세포배양, 핵산증폭검사(nucleic acid amplification test), 항원검사(antigen detection), 유전자조사법(genetic probe method) 등이 있다. 핵산증폭검사가 표준화되지 못한 세포배양 검사를 대신해 표준검사로 사용되고 있다. 그 중 중합효소 연쇄반응검 사(polymerase chain reaction, PCR)는 민감도와 특이도가 각각 83\%93\%, 99.5\%-99.6\%이다[14]. 하지만 비용이 비싸고 모든 기관에서 이 용할 수 없다는 단점이 있다.

국소적 또는 광범위한 복막염을 유발하는 복강내 파급은 골반감염 여성에서 일어난다. 병원균은 직접적으로 전파되거나 림프절 또는 혈 행성으로 전파된다. 또는 진단적 시술에 의해 난관에서 복막으로 전파 되기도 한다. 간주위로 퍼진 간주위염은 갑자기 시작되는 오른위사분 역 통증과 압통이 있으면 임상적으로 의심할 수 있다. 몸을 움직이거나

Table 1. Cases of small bowel obstruction with pelvic inflammatory disease due to Chlamydia trachomatis

\begin{tabular}{|c|c|c|c|c|c|c|c|}
\hline Author & $\begin{array}{c}\text { Age } \\
(y r)\end{array}$ & $\begin{array}{l}\text { Chief } \\
\text { complaint }\end{array}$ & Specimen & $\begin{array}{c}\text { Laboratory } \\
\text { test }\end{array}$ & Radiologic test & $\begin{array}{c}\text { Initial } \\
\text { diagnosis }\end{array}$ & $\begin{array}{l}\text { Treatment } \\
\text { method }\end{array}$ \\
\hline $\begin{array}{l}\text { Baumgardner and } \\
\text { McCanse [10] }\end{array}$ & 24 & Epigastrc pain & Serum & MIF test & Plain radiography & Peritonitis & $\begin{array}{l}\text { Laparotomy } \\
\text { (adhesiolysis) }\end{array}$ \\
\hline Pegg and Owen [8] & 18 & $\begin{array}{l}\text { Abdominal pain, } \\
\text { vomiting }\end{array}$ & Serum & $\begin{array}{l}\text { ELISA, } \\
\text { MIF test }\end{array}$ & N/A & $\begin{array}{l}\text { Appendicitis, } \\
\text { PID }\end{array}$ & $\begin{array}{l}\text { Laparotomy } \\
\text { (adhesiolysis, } \\
\text { appendectomy) }\end{array}$ \\
\hline De and Essex-Cater [9] & 18 & $\begin{array}{l}\text { Lower abdominal } \\
\text { pain, menorrhagia }\end{array}$ & N/A & $\mathrm{N} / \mathrm{A}$ & $N / A$ & SBO & $\begin{array}{l}\text { Laparotomy } \\
\text { (adhesiolysis) }\end{array}$ \\
\hline Abul-khoudoud, et al. [6] & 51 & $\begin{array}{c}\text { Coliky epigastric } \\
\text { and RUQ pain, } \\
\text { postprandial pain }\end{array}$ & Serum & MIF test & $\begin{array}{c}\text { Plain radiography, } \\
\text { ultrasound }\end{array}$ & $\begin{array}{c}\text { Acute } \\
\text { cholecystitis }\end{array}$ & $\begin{array}{l}\text { Laparoscopy } \\
\text { (cholecystectomy, } \\
\text { adhesiolysis) }\end{array}$ \\
\hline Harel et al. [4] & 19 & $\begin{array}{l}\text { Vaginal discharge, } \\
\text { lower abdominal } \\
\text { pain }\end{array}$ & Cervical swab & LCR & $\begin{array}{c}\text { Plain radiography, } \\
\text { CT }\end{array}$ & PID & $\begin{array}{l}\text { Conservative } \\
\text { management }\end{array}$ \\
\hline Oh et al. [11] & 69 & $\begin{array}{l}\text { Abdominal pain, } \\
\text { vomiting }\end{array}$ & Serum & N/A & $\begin{array}{l}\text { Plain radiography, } \\
\text { multidetector CT }\end{array}$ & $\begin{array}{l}\text { Chilaiditi } \\
\text { syndrome }\end{array}$ & $\begin{array}{l}\mathrm{N} / \mathrm{A} \\
\text { (small bowel } \\
\text { resection) }\end{array}$ \\
\hline Burton et al. [5] & 64 & $\begin{array}{l}\text { Nausea, vomiting, } \\
\text { abdominal pain }\end{array}$ & N/A & N/A & $\begin{array}{c}\text { Plain radiography, } \\
\text { CT }\end{array}$ & SBO & $\begin{array}{l}\text { Laparoscopy } \\
\text { (adhesiolysis) }\end{array}$ \\
\hline $\begin{array}{l}\text { Harris and Lambrianides } \\
\text { [7] }\end{array}$ & 18 & $\begin{array}{l}\text { vomiting, } \\
\text { constipation } \\
\text { abdominal pain }\end{array}$ & $\begin{array}{l}\text { Serum, } \\
\text { cervical swab }\end{array}$ & N/A & $\begin{array}{c}\text { Plain radiography, } \\
\text { CT }\end{array}$ & SBO & $\begin{array}{l}\text { Laparoscopy } \\
\text { (adhesiolysis) }\end{array}$ \\
\hline Lee et al. & 17 & $\begin{array}{l}\text { RUQ and } \\
\text { RLQ pain }\end{array}$ & Cervical swab & $P C R$ & $\begin{array}{c}\text { Plain radiography, } \\
\text { CT }\end{array}$ & PID & $\begin{array}{c}\text { Laparotomy } \\
\text { (adhesiolysis, partial } \\
\text { omentectomy } \\
\text { appendectomy) }\end{array}$ \\
\hline
\end{tabular}

MIF, microimmunofluorescence; ELISA, enzyme-linked immunosorbent assay; N/A, not available (not described); PID, pelvic inflammatory disease; SBO, small bowel obstruction; RUQ, right upper quadrant; RLQ, right lower quadrant; LCR, liquid chain reaction; $C T$, computed tomography; PCR, polymerase chain reaction. 


\section{KOREAN JOURNAL OF OBSTETRICS \& GYNECOLOGY}

Ji-Eun Lee, et al. Small bowel obstruction secondary to PID

웃거나, 기침, 심호흡 시 악화된다. 급성 담낭염, 담석증, 위궤양, 췌장 염, 폐렴(하엽), 간염, 신우신염, 급성 맹장염과 감별이 필요하다[6]. 간 피막과 복벽사이 생긴 유착 띠인 특징적인 "violin string sign”의 존재 는 간주위염을 진단할 수 있다.

소장폐쇄는 임상에서 자주 접할 수 있는 질환이다. 장관의 내부 또는 외부 이상이 부분적 또는 완전 소장폐쇄를 일으킨다[2]. 소장폐쇄의 원 인은 유착(67\%-93\%), 탈장(11\%-20\%), 종양, 염증성장질환, 이물질, 장염 $(3 \%)$, 장중첩증 $(4 \%)$, 그리고 선천성 이상들이다[5]. 유착성 장폐쇄 의 대부분은 복강내 수술의 병력이 있는 환자에게서 발생하고 드물게 염증성장질환, 자궁부속기염, 충수돌기염, 게실염 등에서 나타날 수 있 다. 유착성 소장폐쇄 시 컴퓨터단층촬영은 가장 중요한 진단방법이고 다른 기저 질환의 유무도 파악할 수 있다. 컴퓨터단층촬영에서 유착성 소장폐쇄는 단순유착 소장폐쇄(예, 확장된 근위부장고리들과 허탈된 원위부장고리간의 단일 돌발 이행부위)와 폐쇄고리유착 소장폐쇄(예, 두 개 근접한 이행부위들, $\mathrm{C}$ 형 장, 장간막 혈관 등의 방사선 분포)로 분 류할 수 있다[15]. 일단 소장폐쇄가 임상적으로 의심되면, 정확한 진단 과 장허혈의 유무를 판단하는 것은 중요하나 종종 어렵다. 장허혈은 생 명이 위급한 응급 상황이며 특히 어린 나이 환자에게서는 급격히 진행 되어 패혈증과 사망을 초래하므로 적절한 방법으로 대처해야 한다.

소장폐쇄의 치료 원칙은 기저 원인을 규명하고, 응급수술이 필요한 상황인지 비수술적 치료가 가능한 상황인지 결정하는 것이다. 응급수 술이 필요한 상황이 아니면 금식, 수액공급, 항생제와 코위관감압술을 시행하며 관찰할 수 있다. 복부압통이 관찰되고 통증이 악화되는 경우 는 장허혈을 의심할 수 있다. 이러한 환자에게는 즉시 응급수술을 고려 해야 한다. 복부가 팽만해져 있는 장폐쇄는 개복술을 시행하는 것이 전 통적인 방법이었지만 복강경수술의 발달과 장점 때문에 복강경수술이 이상적인 치료방법으로 여겨지고 있다.

C. trachomatis 감염에 의한 골반염증질환과 연관된 소장폐쇄의 빈도 는 세계적으로 8예가 보고되었다(Table 1) [4-11]. Harel 등[4]은 보존 적인 처치를 시행하여 성공적으로 치료하였다. Harris와 Lambrianides [7], Pegg과 Owen [8], De와 Essex-Cater [9], Baumgardner와 McCanse [10]은 개복술로 유착을 박리하였으며 Burton 등[5]과 AbulKhoudoud 등[6]은 복강경수술을 통해 유착박리를 하여 소장폐쇄의 수 술적 치료로 복강경수술의 시행 가능성을 확인시켜 주었다. Chilaiditi syndrome은 간과 우측 횡격막 사이에 장관의 일부과 일시적 혹은 영 구적으로 위치하게 되는 상태인데 Oh 등[11]은 복통과 구토를 하는 69 세 여자 환자의 단순복부촬영과 복부골반 컴퓨터단층촬영에서 소장폐 쇄를 동반한 Chilaiditi syndrome으로 진단된 증례를 보고하였다. 수술 을 통해 과거에 간주위염을 않은 적이 있음을 시사하는 간과 전 복벽 사이의 유착띠, violin string sign이 발견되었고 그 유착띠 사이에 회장 이 폐쇄고리를 형성하며 소장폐쇄가 발생했다. 소장은 괴사되어 부분 절제술이 시행되었다.

본 증례는 C. trachomatis 골반염증질환의 급성 후유증으로 발생한 소장폐쇄에 대해 국내에 보고된 첫 증례이다. Oh 등[11]의 증례는 환자 가 외과로 입원하여 수술 중 수술 소견에서 violin string sign이 관찰되
었고 술 후 혈청 C. trachomatis 항체검사를 시행하여 후향적으로 간주 위염이 진단되었고 소장 폐쇄가 간주위염의 후기 만성 합병증으로 발 생하였다는 점에서 본 증례와 차이가 있다. 본 증례는 보존적 처치 중 소장폐쇄 증상이 개선되지 않고 증상이 악화되어 장허혈이 발생하여 장괴사가 임박해 응급수술을 시행한 경우이다. 환자에 대한 주의 깊은 경과관찰, 외과의사와의 협진, 컴퓨터단층촬영을 이용한 신속한 진단 과 응급수술로 심각한 합병증, 즉 패혈증, 장절제 등의 발생을 막을 수 있었다. 골반염과 동반된 오심 구토 증상이 지속될 경우 골반염의 드문 합병증인 장폐쇄를 의심해야겠고, 단순복부촬영에서는 폐쇄고리에 의 한 소장폐쇄이거나 복수가 많을 경우 소장폐쇄 소견이 저명하지 않을 수 있고 늦게 나타나는 경향이 있으며 장허혈 상태를 진단하기 어려울 수 있기 때문에 정확한 진단과 의사결정을 위해 복부 단순촬영뿐만 아 니라 복부골반 전산화단층촬영이 유용할 수 있다.

\section{References}

1. Lee JW, Cho HC, Choi KY, Bae DH, Kim HJ. Application of nested pcr for the detection of chlamydia trachomatis in diagnosis and monitoring the patients with pelvic inflammatory disease and vaginitis. J Soonchunhyang Med Coll 2001;7:301-5.

2. Bolton JP, Darougar S. Perihepatitis. Br Med Bull 1983;39:15962.

3. Eschenbach D. Pelvic infections and sexually transmitted diseases. In: Danforth DN, Scott JR, editors. Danforth's obstetrics and gynecology. 8th ed. Philadelphia (PA): Lippincott Williams \& Wilkins; 1999. p.594-5.

4. Harel Z, Tracy TF Jr, Bussey JG 3rd. Small bowel obstruction in an adolescent with pelvic inflammatory disease due to Chlamydia trachomatis. J Pediatr Adolesc Gynecol 2003;16:125-8.

5. Burton E, McKeating J, Stahlfeld K. Laparoscopic management of a small bowel obstruction of unknown cause. JSLS 2008;12:299-302.

6. Abul-Khoudoud OR, Khabbaz AY, Butcher CH, Farha MJ. Mechanical partial small bowel obstruction in a patient with Fitz-Hugh-Curtis syndrome. J Laparoendosc Adv Surg Tech A 2001;11:111-4.

7. Harris C, Lambrianides AL. Small bowel obstruction secondary to pelvic inflammatory disease. Am Surg 2011;77:E80-1.

8. Pegg DJ, Owen AW. Gastrointestinal obstruction associated with Chlamydia trachomatis. Genitourin Med 1990;66:26-7.

9. De K, Essex-Cater AJ. Gastrointestinal obstruction associated with Chlamydia trachomatis. Genitourin Med 1990;66:408.

10. Baumgardner DJ, McCanse DE. Peritonitis and small bowel obstruction. IMJ III Med J 1987;171:75-8. 


\section{KOREAN JOURNAL OF OBSTETRICS \& GYNECOLOGY}

KJOG Vol. 55, No. 4, 2012

11. Oh SN, Rha SE, Byun JY, Kim JY, Song KY, Park CH. Chilaiditi syndrome caused by Fitz-Hugh-Curtis syndrome: multidetector CT findings. Abdom Imaging 2006;31:45-7.

12. Kim JO, Yun IY, Chung DY, Jo BC, Song SK. A clinical evaluation of chlamydia trachomatis infection in women. Korean J Obstet Gynecol 2002;45:1827-34.

13. Workowski KA, Berman S; Centers for Disease Control and Prevention (CDC). Sexually transmitted diseases treatment guidelines, 2010. MMWR Recomm Rep 2010;59:1-110.
14. Cook RL, Hutchison SL, Østergaard L, Braithwaite RS, Ness RB. Systematic review: noninvasive testing for Chlamydia trachomatis and Neisseria gonorrhoeae. Ann Intern Med 2005;142:914-25.

15. Delabrousse E, Lubrano J, Jehl J, Morati P, Rouget C, Mantion $G A$, et al. Small-bowel obstruction from adhesive bands and matted adhesions: CT differentiation. AJR Am J Roentgenol 2009;192:693-7.

\section{Chlamydia trachomatis 골반염증질환과 관련된 유착성 소장폐쇄 1예}

인제대학교 상계백병원 ${ }^{1}$ 산부인과학교실, ${ }^{2}$ 외과학교실, ${ }^{3}$ 병리학교실

이지은 ${ }^{1}$, 김명환 ${ }^{1}$ 최 훈, 고지경', 이철민', 조용균 ${ }^{1}$, 김복린', 양근호', 권지은 ${ }^{3}$

17 세 여자가 골반염증성질환으로 입원하여 항생제 치료를 시작하였다. 증상 호전 중 입원 5일째 갑자기 오심과 구토 증상이 시작되었 다. 보존적 처치에도 불구하고 증상이 심해져 7일째 시행한 단순복부촬영과 복부골반 전산화단층촬영에서 허혈성 소장폐쇄 소견이 보였 다. 응급개복술을 시행하였고 소장 장간막 부위에 그물막이 붙어 유착띠가 형성되어 있었고 $20 \mathrm{~cm}$ 정도의 소장이 끼어 있었다. 부분 그 물막절제술, 유착띠박리술, 부수적으로 충수돌기절제술을 시행하였다. 수술 후 증상은 완전히 소실되었으며 11 개월간 외래 추적 관찰에 서도 특이사항은 없었다. 이 증례는 골반염과 동반된 오심 구토 증상이 지속될 경우 골반염증질환의 드문 합병증인 장폐쇄를 의심하여야 하겠고, 정확한 진단과 의사결정을 위해 단순복부촬영뿐만 아니라 복부골반 전산화단층촬영의 유용성을 보여준다. 저자들은 Chlamydia trachomatis 감염에 의한 골반염성 질환 환자에서 발생한 유착성 소장폐쇄 1예를 경험하였기에 이에 간단한 문헌 고찰을 함께 보고하는 바이다.

중심단어: 소장폐쇄, 골반염증질환, Chlamydia trachomatis 